\title{
Contemporary Icarus: Gustav von Aschenbach's Journey towards the Sun
}

\section{SUMMARY}

The point of departure for the reflections contained in this article is the motif of the sun in Tomasz Mann's Death in Venice. Analysing the presence of the sun in the work turns out to be fruitful for distinguishing and connecting several symbolic planes, on which the issues of Death in Venice and the drama of the main character are depicted: the relationship between contemporary times and antiquity, the cultural North-South axis, the destructive power of beauty as well as the individual fate of the artist marked by decadence. The figure of the sun seems to provide material for the interpretation of the figure of Gustav von Aschenbach as an incarnation of contemporary Icarus and allows the reader to see the path which the protagonist of Death in Venice follows in a new light.

\section{Keywords}

Venice, Mann, sun, mythology, love, decadence, novella

Death in Venice by Thomas Mann belongs among the masterpieces of European literature and as such has been the subject of a considerable number of analyses, studies and interpretations. The work itself encourages such actions: it contains many symbols, metaphors and allusions, which sometimes allow researchers to obtain coherent findings and sometimes make them arrive at contradictory conclusions. Moreover, due to these voices, which 
enrich the discourse on the reception of the work, the discussion around the novella written in 1911 remains vivid to this day, and the reading of the work may still bring interesting reflections.

Many symbolic contexts appearing in Death in Venice were subject to in-depth analysis both in the foreign critical and artistic reception as well as in the reflections of eminent Polish humanists who explored such aspects of the work as the universal myth of Venice in the European culture, the symbolism of water, and the motif of death as explored by Dariusz Czaja. ${ }^{1}$ Paweł Pieniążek's text on the moral fall of the protagonist draws attention, in turn, to transgression and rebellion of the lonely individual. It is also impossible not to mention the erudite sketch titled "Muzyka wenecka" [Venetian Music $]^{2}$ by Ewa Bieńkowska, who looked at the cult of form, the sinful obsession with perfection and getting to know the reality in its entirety as manifested by Mann's protagonist. ${ }^{3}$ Evidence of artistic inspirations and traces of the reception of the author of Tonio Kröger may be also found in Witold Gombrowicz's Trans-Atlantyk and novels by Philip Roth or essay writing by Wojciech Karpiński, which certainly does not close the catalogue of artists and critics still entering into dialogue with Death in Venice and its author.

The aim of this work is also to draw attention to the importance of another motif appearing in the work, namely the presence of the sun, an aspect which so far has not found a place in the literary reflections. The symbol of the sun is present in the story in several ways: it appears not only as the weather craved by tourists, but it also gives grounds for a number of mythological associations that allow the reader to look at the main character from a different perspective.

"Yes, this was Venice, this the fair frailty that fawned and that betrayed, half fairy-tale, half snare"t" this is what the narrator says about the city, which is the rightful - if not the leading - character of Mann's story. This thought could be the starting point for a reflection on Gustav von Aschenbach's journey to Venice as gravitating towards the pulsating sensual centre of the world, a spiritual and intellectual journey, which will cost the protagonist his life.

\section{Spiritual topography}

The main protagonist of Death in Venice is Gustav von Aschenbach, an acclaimed writer over 50 years-old who was ennobled in honor of his artistic achievement and whose name can be found in school textbooks. He is said to owe his fame to hard work, self-discipline and severity - qualities which

\footnotetext{
${ }^{1}$ Dariusz Czaja, "Wenecja i śmierć. Konteksty symboliczne," Polska Sztuka Ludowa - Konteksty, no. 3-4 (1992): 58-65.

${ }^{2}$ Ewa Bieńkowska, "Muzyka wenecka," in Ewa Bieńkowska, W poszukiwaniu królestwa człowieka. Utopia sztuki od Kanta do Tomasza Manna (Warsaw: Czytelnik, 1981).

${ }^{3}$ A review of interpretive strategies or keys according to which researchers have analysed Thomas Mann's Death in Venice can be found in the habilitation dissertation by Marcin Wołk. Cf. Marcin Wołk Głosy labiryntu. Od "Śmierci w Wenecji” do "Monizy Clavier" (Toruń: Wydawnictwo Naukowe Uniwersytetu Mikołaja Kopernika 2009), 34-54.

${ }^{4}$ Thomas Mann, Death in Venice, trans. Helen Tracy Lowe-Porter, in Short Novels by the Masters, ed. Charles Neider (New York: Cooper Square Press, 2001), 482.
} 
he inherited from his ancestors. However, its origin was marked by duality: there was both Germanic and Slavic blood in his veins. "The union of dry, conscientious officialdom and ardent, obscure impulse, produced an artist and this particular artist." ${ }^{5}$

At one point, however, the horizon of this stable and predictable life, whose rhythm was determined by hours of arduous work, was crossed by the need for travel, previously unknown to Aschenbach, which is why he eventually boarded a ship sailing to Venice. This change of scene - from rainy Munich, where the writer settled down, to the sunny pearl of the Adriatic, as the Italian city he decided to go is referred to - is also a symbolic journey. It seems to echo the Romantic discussion about the clash of two visions of culture identified by the literature of Northern Europe and the Mediterranean civilisation. For Thomas Mann, who travelled to Italy many times, the North-South opposition "could have appeared to be a problem of irreconcilable bipolarity, simultaneously essential principles of development, two forms of knowledge about life." ${ }^{\prime \prime}$ The drama - or at least the internal conflict - of the main protagonist of Death in Venice is constructed from the tension between these two values.

Aschenbach's sudden departure was an escape from these two orders Germanic and Slavic ones - towards Mediterranean culture. "This yearning for new and distant scenes, this craving for freedom, release, forgetfulness - they were, he admitted to himself, an impulse towards flight," ${ }^{\prime 7}$ as the narrator comments on the character's undertakings. The Slavic element, characterised in the novella as more sensual, closer to nature than culture, only made Aschenbach gravitate even more to the culture of the South. The division of Europe into Germanic and Latin worlds is symbolically highlighted by the presence of the sun. Needless to say, cultural records tend to generate images of the cloudy, gloomy North and the sunny, lazy South.

This is also the case with this writer's journey, whose purpose was by no means accidental. As Ewa Bieńkowska points out:

two cities play a special role in this writing, acting as cities of individuality, distinctive and endowed with their own soul (...) these two cities are Lübeck and Venice, which mark the axis crossing Europe at two ends. It is therefore not only history but also geography - in the spiritual and symbolic sense. ${ }^{8}$

The southern direction was extremely popular among the European intelligentsia. From the middle of the 18th century, Italy "was - especially for Germans - a holy country, a place of pilgrimage, where one did not so much go to obtain one's education as to touch the holy springs, to immerse oneself in the primordial - that is, pure and perfect - matter of civilisation."

\footnotetext{
${ }^{5}$ Mann, Death in Venice, 443.

${ }^{6}$ Ewa Bieńkowska, W poszukiwaniu królestwa człowieka. Utopia sztuki od Kanta do Tomasza Manna (Warsaw: Czytelnik, 1981), 282.

${ }^{7}$ Mann, Death in Venice, 442.

${ }^{8}$ Bieńkowska, W poszukiwaniu królestwa człowieka..., 281.

${ }^{9}$ Ibid., 282.
} 
A journey to Venice is both an experience which is intellectual and aesthetic. Not only does this refer to the unique architecture of the city, but also to the sensual experience of the play of light and water. As Peter Ackroyd argues:

The light of Venice is as important as its space and form. The light on the water casts illumination upwards and outwards. The sunlight plays upon the walls and ceilings, with an incessant rippling effect. (...) But the characteristic of Venice is a pale soft light, like a drifting haze, powdered, part wave and part cloud. It is a pearly iridescent light wreathed in mist. It is drawn from the horizon and the sea as much as from the sun. It lends everything unity. ${ }^{10}$

This Venetian marriage of sun and water is also reflected in the rich symbolism of the city. One of the symbols is a lion, which "combines a twofold power, fire and water, so that it belongs - like many other symbolic animals, such as a horse and an ox - not only to the sun, but also to the earthly waters and their reproductive power."11 This animal, therefore, fits between the two elements, the sun and water, so important for Venice and essential for Mann's novella. In the city of St. Mark, lions appear on the buildings in the form of numerous gargoyles; there is also a multitude of lion sculptures and bas-reliefs, for instance on the Doge's Palace. Walking through Venice, Aschenbach notes houses with "little lion balconies." ${ }^{12}$ However, the sculpture on the entrance gate to the city is the most famous: the Venetian lion has wings and keeps one paw on an open book, the Gospel of St. Mark, who is the patron saint of Venice. Just like the Mycenaean lions that guarded the gates to the city "hold a column of the sun and symbolise divine care,"13 the symbol of Venice was supposed to "protect the city from the enemy (hence, the statues of lions in the Venetian Arsenal) or epidemics as well as protect the city if necessary." ${ }^{\prime 14}$ As Henryk Sienkiewicz noted after visiting the Doge's Palace: "The face of this Republic emerges from the darkness of history, marble, proud, mighty, with lion's wrinkles on its forehead, or as if wrathful, angry, bloodied, soulless and without a star - an idea above its head."15 The marble lion face of Venice, once a symbol of invincible power, has become the embodiment of past greatness inextricably linked to the idea of the sun.

In Death in Venice, however, the Italian city is not eternally bathed in sunshine. Admittedly, the story is set in Venice in the summer, but the architecture of the city makes the buildings floating on the water absorb

${ }^{10}$ Peter Ackroyd, Venice: Pure City, (New York: Random House, 2009), 146, accessed October 24, 2020, https://kingauthor.net/books/Peter\%20Ackroyd/Venice/Venice\%20-\%20 Peter\%20Ackroyd.pdf.

${ }^{11}$ Dorothea Forstner, Świat symboliki chrześcijańskiej (Warsaw: Instytut Wydawniczy PAX, 1990), 276 as cited in Aleksandra Achtelik, Wenecja mityczna w literaturze polskiej XIX i XX wieku (Katowice: Wydawnictwo Gnome, 2002), 141.

${ }^{12}$ Mann, Death in Venice, 495.

${ }^{13}$ Achtelik, Wenecja mityczna..., 140.

${ }^{14}$ Ibid.

${ }^{15}$ Henryk Sienkiewicz, Dzieła, vol. XLIV (Warsaw: Państwowy Instytut Wydawniczy, 1950), 185, as cited in Aleksandra Achtelik, Wenecja mityczna..., 141. 
moisture and retain the sun's rays, which is why Aschenbach strolls through the damp, musty streets that are marked by deadly odours. Only the vast sandy beaches of Lido Island are sunny, and this is where Aschenbach could achieve full happiness, observing teenage Tadzio. The sun present in the novella is also a sign of a certain sensuality, intoxication accompanying the contemplation of beauty. The sun and the beauty, intertwined with each other, have a great impact on Aschenbach: the sun intensifies the ecstatic experience and strengthens the homoerotic fascination with the boy.

Falling in love for the first time in years and the rush of inspiration after experiencing writer's block - all this makes Gustav not only feel younger, but also start to pay more attention to his appearance. The inner transformation is marked by a shift from austerity and sexual constraint to corporeality and sensual pleasure.

\begin{abstract}
Has it not been written that the sun beguiles our attention from things of the intellect to fix it on things of the sense? The sun, they say, dazzles; so bewitching reason and memory that the soul for very pleasure forgets its actual state, to cling with doting on the loveliest of all the objects she shines on. Yes, and then it is only through the medium of some corporeal being that it can raise itself again to contemplation of higher things. ${ }^{16}$
\end{abstract}

The narrator makes clear allusions to Plato's dialogues. It is due to, among other things, the influence of nature that Aschenbach's thoughts are directed towards images drawn from ancient culture.

And the sea, so bright with glancing sunbeams, wove in his mind a spell and summoned up a lovely picture: there was the ancient plane-tree outside the walls of Athens, a hallowed, shady spot, fragrant with willow-blossom and adorned with images and votive offerings in honour of the nymphs and Achelous. ${ }^{17}$

Sensory impressions - the noise of the sea and the glow of the sun - appeared to be a direct connection with the world of ancient Latin culture. It was not only about the aesthetic aspect, but also the ethical one, since beauty was connected with morality in the ancient world: what was beautiful was valued positively. Beauty was a sign of the presence of the gods, an expression of their approval - it belonged, at the same time, to the sphere of the sacred.

\title{
Goodness and beauty or sin and death?
}

Tadzio - the incarnation of divine order - is the highest beauty in Death in Venice. For the writer, contact with the boy is an encounter with finished perfection: he is struck by his beauty. In order to describe Tadzio's beauty, Aschenbach's imagination draws on pictures of ancient sculptures.

\footnotetext{
${ }^{16}$ Mann, Death in Venice, 473.

${ }^{17}$ Ibid.
} 
Aschenbach noticed with astonishment the lad's perfect beauty. His face recalled the noblest moment of Greek sculpture - pale, with a sweet reserve, with clustering honey-coloured ringlets, the brow and nose descending in one line, the winning mouth the expression of pure and godlike serenity. ${ }^{18}$

The above description is very suggestive: Tadzio looks like a Greek statue in the eyes of Aschenbach. However, the portrait of the boy drawn in this way also brings to mind other associations, namely that with the lion, the symbol of Venice, suspended between the elements of the sun and water, and perhaps even with the sun itself. "His facial tint was ivory-white against the golden darkness of his clustering locks," as the description continues. He had a fine head of golden hair which was never cut by the barber, "dusky clustering ringlets standing out in soft plenteousness over temples and ears. ${ }^{19}$

A certain analogy between the boy and the sun highlights how important Tadzio was to Aschenbach: he quickly became the focal point of his existence during his stay in Venice. It is to the Pole who the writer adjusts his days, and it is to his activities that he tries to fit in when arranging the schedule of his day. "He went, indeed, early to bed, for at nine o'clock, with the departure of Tadzio from the scene, the day was over for him."20

Contemplating the boy's beauty, watching him play on the beach tends to be combined with the mention of the scorching sun: it is usually in such circumstances that the characters meet. However, the narrator does not fail to mention that the sun deceives Aschenbach's senses and the heat on the beach only intensifies his fascination with Tadzio, taking him even further into the sphere of the sacred: "Thus the lad's foreign birth raised his speech to music; a wanton sun showered splendour on him, and the noble distances of the sea formed the background which set off his figure." ${ }^{21}$ As if only the sun was the ideal environment for this "phenomenon," if not a catalyst for all Aschenbach's imaginations related to the world of ancient culture.

Years after publishing Death in Venice, Thomas Mann admitted in a private letter that he portrayed Tadzio in the shape of Hermes Psychopomp, Guide of the Dead. The author of Buddenbrooks was particularly fond of a sculpture by Lyssipos, a copy of which he saw in a museum in Berlin. It shows Hermes resting with one leg forward.22 This was also the position which Tadzio assumed when Aschenbach saw him for the first time: "The observer saw him in half profile, with one foot in its black patent leather advanced, one elbow resting on the arm of his basket-chair, the cheek nestled into the closed hand in a pose of easy grace, quite unlike the stiff subservient mien which was evidently habitual to his sisters. ${ }^{23}$

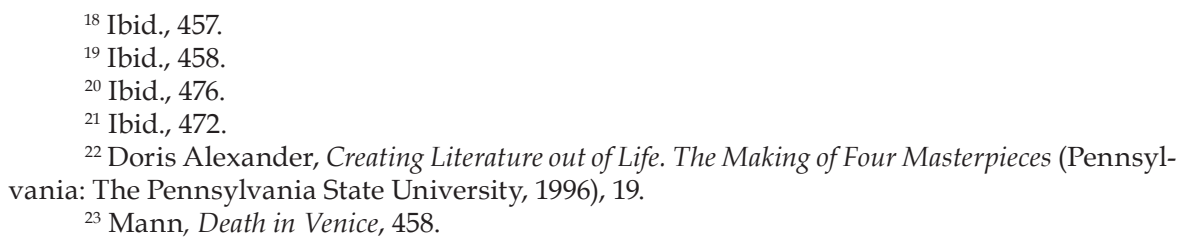


In addition to being the emissary of the gods, Hermes was a conductor of the souls of the dead to Hades. ${ }^{24}$ Tadzio acted as such a guide for Aschenbach in his journey into the afterlife. In the last moments of his life, seeing a boy on the beach, he calls him a psychogogue, which in Greek denotes "leading souls." 25

The identification of the boy with this god makes Tadzio the simultaneous embodiment of beauty, art and death. He is a danger that comes with the contemplation of beauty. Such a view marks art with a certain ambiguity: it has the potential both to create and to destroy. It is able to "build" the soul, fill it with joy and elevate it. At the same time, however, it has a destructive element capable of bringing the soul down to the other world.

Traditionally, Hermes was also responsible for sending dreams and, in this respect, he was an intermediary of Zeus. ${ }^{26}$ Indeed, during his stay in Venice, Aschenbach is haunted by dreams filled with mythological content. These dreams are in a way the consequence of the change to his state of mind: they accompany the inner transformation of the writer; they are a sign of the exuberant life of his soul. For the reader, they are a visible sign of his fall, another step towards an insane, destructive infatuation.

Hermes was the patron saint of travellers as the one who easily moved on all trade routes (he also looked after trade and merchants). ${ }^{27}$ After all, by order of the gods, he was their Messenger: he was skilful at fulfilling their wishes, moving energetically, with golden wings at his feet helping him. ${ }^{28}$ Thus, from the beginning of Death in Venice, Hermes was also the patron of Aschenbach: his star guided him from the moment the writer felt the call of the journey, when he felt an unknown urge to change his place of residence. Previously, as the narrator informs, he despised journeys that he considered distracting from the gist of things. After all, his whole being was striving for fame: Aschenbach knew his destiny, namely success ensured by his excellent writing. A trip did not fit into the regime of his everyday life. Yet, all of a sudden, everything changes, and the willingness to travel is accompanied by the appearance of Hermes on stage.

\section{The Apollonian element}

It is impossible not to mention the other patrons from the Greek imaginarium, Apollo and Dionysus who seem to be pervade Death in Venice. The struggle of these two elements turned out to be an extremely fertile and capacious sign in culture and philosophy, also with reference to Thomas Mann's novella. Paweł Pieniążek points out that in Venice, Gustav Aschenbach is in the possession of those very gods who fight for his

${ }^{24}$ Zdzisław Piszczek, Mała encyklopedia kultury antycznej (Warsaw: PWN, 1983), 314. word,63594.

${ }^{25}$ Encyklopedia Gutenberga, accessed April 27, 2020, http://www.gutenberg.czyz.org/

${ }^{26}$ Piszczek, Mała encyklopedia kultury antycznej, 314.

${ }^{27}$ Ibid.

${ }^{28}$ Albert Zipper, Mitologia Greków i Rzymian (Złotów: Wydawnictwo Księgarni Wilhelma Zukerkandla, 1896), 106. 
soul. Ultimately, Dionysus triumphs and he takes over the character's consciousness. ${ }^{29}$ Indeed, in the end, what prevails are the Dionysian pleasures, such as a fondness for corporeal values. The victory of Dionysus in this battle for the soul of the Aschenbach is manifested by his last dream, being a cruel, disconcerting vision of a march posed as a Bachus-like procession, in which naked women carried torches, daggers and snakes in their hands, and hairy, horned men walked surrounded by goats (another symbol of Dionysus). The dream was accompanied by orgiastic elation, and the characters appearing in this vision behaved lewdly: "They laughed, they howled, they thrust their pointed staves into each other's flesh and licked the blood as it ran down," ${ }^{30}$ they sacrificed animals to the gods. In the background, there was a clear flute sound. This dream brought Aschenbach ambiguous pleasure: "And in his very soul he tasted the bestial degradation of his fall." ${ }^{31}$ In the dream, "the dreamer was in them and of them, the stranger god was his own." ${ }^{\prime 32}$ Which god would Tadzio belong to if he was the recipient of this allusion?

The battle for the protagonist's soul can also be perceived in a different way. Perhaps the final blow that brought the protagonist down fell from another ambivalent side, namely from Apollo. He became a synonym for beauty for us today, although the ancients had far more mixed feelings about him. "He had power over all human life. He was the god of spring, the god of sea travel (Delfinios), he looked after agriculture and cattle, he took care of health, healed, but also sent the plague." ${ }^{33}$ He was depicted with a bow and an armful of arrows, which he received from Hephaestus: it was believed that any sudden death was caused by Apollo. "If someone died a painless death, especially in old age, it was said that Apollo's gentle arrow sent a death on them." ${ }^{34}$ He was also believed to have sent a plague to the Greek camp with his arrows ${ }^{35}$ and to have been responsible for the spread of the epidemic, ${ }^{36}$ sometimes with the use of his arrows. Thus, he was a punishing god "striking far off," ${ }^{\prime 37}$ and destructive powers were attributed to him: this meaning was read from his name associated with the

\footnotetext{
${ }^{29}$ Paweł Pieniążek, Akademia dekadencji, in Edward Białek, Grzegorz Kowal, Arcydzieła literatury niemieckojęzycznej, vol. 2 (Wrocław: ATUT, 2011).

${ }^{30}$ Mann, Death in Venice, 492.

${ }^{31}$ Ibid.

${ }^{32}$ Ibid.

${ }^{33}$ Piszczek, Mała encyklopedia kultury antycznej, 61.

${ }^{34}$ Ibid., 79.

${ }^{35}$ In the writings of Pausanias, there is a mention of the story of sending a plague upon the city of Argos. This was punishment for killing Apollo's son whom he begot with the daughter of Coroebus, the King of Argos. The child was torn apart by the monarch's sheepdogs. As punishment, Apollo sent Poena [i.e. Punishment] upon the city. Poena was believed to have been snatching children from their mothers until Coroebus much to the joy of Argives. Yet after this murder, another misfortune fell on the city. The bubonic plague. And it persisted." Pausanias, Wẹdrówka po Helladzie. Księgi I-X, the computer edition (2003), 137, accessed April 30, 2020, http://biblioteka.kijowski.pl/antyk\%20grecki/\%20pauzaniasz\%20-\%20 w\%E4\%99dr\%E3\%B3wka\%20po\%20helladzie\%20ks.1-10.pdf.

${ }^{36}$ William Smith, A dictionary of the Greek and Roman Biography and Mythology (Boston: Little, 1887), 230.

${ }^{37}$ Miszczek, Mała encyklopedia..., 79.
} 
Greek word denoting "to destroy." 38 Another hypothesis about the origins of the name Apollo is that it means the one who protects against evil and punishes those who are at fault. ${ }^{39}$ The administration of justice was to be the primary, original occupation of the Olympic god. Human and animal life also depended on him. "That is why during a plague (...) solemn prayers were sent to Apollo." ${ }^{\prime 0}$ In this light, the Venice which Aschenbach visited becomes the arena of Apollo's actions. The city was struck by a plague, and the traveller met a sudden death which may have been caused, as the ancients believed, by the Greek god. But what is most remarkable, Apollo used to be associated with Helios and Sol, the god of the sun, or with the sun itself, traces of which can be found in ancient legends. ${ }^{41}$

What was the fault of the protagonist of Death in Venice? All in all, Aschenbach did not take any action, so it was not for his actions that he could be punished. The domain of immoral "deeds" was the writer's imagination: his conscience is burdened both by his erotic fascination with the underage boy and by his excessive trust with sensual sensations, for which, paradoxically, only his fantasy was responsible. These feelings are connected both to solar mythology and to the meaning of the sun in the thought of ancient poets and philosophers.

The sun, as it was previously suggested, is a symbol of sensual experience, carnal pleasure. And this is what Death in Venice is also about: in a similar way as The Immoralist by André Gide (1902), it deals with the issue of the awakening of homosexuality. As Michel Foucault argued, the of topic of homosexualism did not appear until the 20th century, and indeed it was explored by, for instance, Sigmund Freud, at the beginning of the 20th century. His Three Essays on the Theory of Sexuality from 1905 were to influence the final shape of Mann's work. ${ }^{42}$ From a psychoanalytic point of view, Aschenbach's sexuality was dormant, bound by the strict bourgeois morality. In addition, the voyeuristic ways of adoring the boy points to a certain defect, to the incompleteness of this sphere of life. The appearance of the tiger in the old artist's visions announces a period of transformation - the beginning of the process of sexual self-awareness. Apollonian-Dionysian dualism, drawn from Nietzsche's writings, would be an allusion to this transformation of the traveller's identity. These theories are supported by the solar mythology, used in the works of Carl Gustav Jung, who was a student of Freud. In his opinion, the vital force, or libido, manifests itself in the form of the sun. ${ }^{43}$ Under its influence, the dormant sexuality of an aging writer would come to light.

\footnotetext{
${ }^{38}$ Smith, A dictionary..., 230.

${ }^{39}$ Ibid.

${ }^{40}$ Piszczek, Mała encyklopedia..., 80.

${ }^{41}$ Smith, A dictionary..., 231.

${ }^{42}$ Louise Willis, The Representation of Instinctive Homosexuality and Immoral Narcissism in Gide's The Immoralist (1902) and Mann's Death in Venice (1912), CLCWeb: Comparative Literature and Culture (2017), 3, accessed April 27, 2020, https://doi.org/10.7771/1481-4374.2960.

${ }^{43}$ Monika Jaworska-Witkowska, “Nienasycenie i 'niewygasła żywotność archetypu wielkiej matki. Misterium 'rodzącego łona' jako symbol uniwersalizmu tworzenia," Rocznik Naukowy Kujawsko-Pomorskiej Szkoty Wyższej w Bydgoszczy. Transdyscyplinarne Studia o Kulturze
} (i) Edukacji, no. 7-8, 95. 
Thanks to the throes of passion, the writer feels an urgent need to create. The boy's beauty and harmony in the shape of his silhouette provoke Aschenbach to write. The teenager's body was a model of style for him: he wanted the form of his work to be a perfect representation of the appearance of the adored child. The artist aimed that "he would snatch up this beauty into the realms of the mind, as once the eagle bore the Trojan shepherd aloft." 44 This is yet another allusion to mythology: the Trojan shepherd was Ganymede, who attracted the attention of the gods with his extraordinary beauty. Zeus, in the form of an eagle, was to go down to Earth and abduct the Prince, thus ensuring him immortality. ${ }^{45}$ This is the kind of immortality that Aschenbach wanted: using his pen, he wished to capture the wonderful looks of Tadzio, to transform physical beauty into spiritual beauty, to refine what is sensual by shifting it to the sphere of ideas. The writer seems to be triumphing: thanks to this divine inspiration, a sample of excellent writing is created, "that page and a half of choicest prose, so chaste, so lofty, so poignant with feeling, which would shortly be the wonder and admiration of the multitude." ${ }^{\prime 46}$

\section{Contemporary Icarus}

The fate of Aschenbach was cruel: he was killed in Venice by cholera brought from India. He died because of his own inattention, having eaten some infected strawberries. But on a symbolic plane, Mann seems to suggest another cause of death. Aschenbach appears to have been walking towards a fall from the beginning: the construction of the work with death in the title acquaints the reader with the ending from the very beginning, immediately suggesting an unfavourable course of events.

It may be destiny: everything takes place according to the plan, and the traveller surrenders to the action of the gods. He succumbs to the visions of the jungle and tigers and sets off on a journey, falls in love with a boy who is apparently a personification of the gods and ends his life in almost orgiastic ecstasy. It is the fate that the artist meets for choosing his profession, for deciding to worship beauty above all. In Germany, Aschenbach succeeded in resisting the destructive effects of aesthetic charm, imposing on himself the strict framework of a passionless everyday life. The journey to Venice ruins this apparent harmony: the gods and beauty demand praise. The rules of Protestant self-restraint cease to apply on Lido Island, and the hot sun awakens passions.

It is difficult to resist the impression that Aschenbach is constantly walking towards the sun. His aspirations are Tadzio, love, beauty, art - all this comprises the picture of the sun in the story. There is still one more element pertaining to the symbol of the sun - death. This fatal power personified by Thanatos, a companion of Eros in Freud's psychoanalytical theory, has an impact on the protagonist from the very beginning.

\footnotetext{
${ }^{44}$ Mann, Death in Venice, 474.

${ }^{45}$ Zipper, Mitologia Greków i Rzymian, 48.

${ }^{46}$ Mann, Death in Venice, 475.
} 
An in-depth analysis of the presence of the sun in Mann's work makes it possible to notice also the fragments that refer to the scorching power of the sun or, directly, to burning. This is not only about the myth of Semele, who was, as the narrator says, "consumed by love." 47 The sand is burning and the sunrise that Aschenbach saw in his dream resembles a fire: "from horizon to zenith went great quivering thrusts like golden lances, the gleam became a glare; without a sound, with godlike violence, glow and glare and rolling flames streamed upwards, and with flying hoof-beats the steeds of the sun-god mounted the sky." ${ }^{\prime 4}$ This is a description of Aschenbach's work in which Sebastian is one of the protagonists: ${ }^{49}$

Within that world of Aschenbach's creation were exhibited many phases of this theme: there was the aristocratic self-command that is eaten out within and for as long as it can conceals its biologic decline from the eyes of the world; the sere and ugly outside, hiding the embers of smouldering fire - and having power to fan them to so pure a flame as to challenge the supremacy in the domain of beauty itself; the pallid languors of the flesh, contrasted with the fiery ardours of the spirit within, which can fling a whole proud people down at the foot of the Cross, at the feet of its own sheer self-abnegation..$^{50}$

Fire also denotes emotional suffering: youth, being a reflection of divine beauty, "sets us afire with pain and longing." 51

It is also worth paying attention to frequent mentions about ascending which results in the case of Aschenbach from personal aspirations. "Aschenbach's whole soul, from the very beginning, was bent on fame," 52 "This was he who had put knowledge underfoot to climb so high; who had outgrown the ironic pose and adjusted himself to the burdens and obligations of fame." ${ }^{13}$ Flying and floating move the reader's attention towards mythology and ancient philosophy. Zeus abducts Ganymede to Olympus, and the soul, as Socrates argued in Plato's dialogues, has wings and it ascends to the sky so as to be closer to the gods. Above all, a soul in love is winged, a soul seeking the beloved in whom it finds a divine beauty. "The divine is beauty, wisdom, goodness and the like; and by these the wing of the soul is nourished, and grows apace," 54 as the philosopher says. It is worth quoting once again the passage describing the fatal power of the sun:

${ }^{47}$ Mann, Death in Venice, 474.

${ }^{48}$ Ibid., 477.

${ }^{49}$ St. Sebastian, who died a martyr's death, was also the patron saint of those suffering from infectious diseases. Eva Brann, The Venetian Phaedrus, St. John's College Digital Archives, accessed April 28, 2020, http://digitalarchives.sjc.edu/items/show/1234, 3.

${ }^{50}$ Mann, Death in Venice, 466.

${ }^{51}$ Ibid., 473.

52 Ibid., 443.

${ }^{53}$ Ibid., 495.

${ }_{54}$ Plato, The Phaedrus, trans. Benjamin Jowett, The Project Gutenberg EBook of Phaedrus, last modified January 15, 2013, accessed October 25, 2020, http://www.gutenberg.org/ files/1636/1636-h/1636-h.htm. 
The sun, they say, dazzles; so bewitching reason and memory that the soul for very pleasure forgets its actual state, to cling with doting on the loveliest of all the objects she shines on. Yes, and then it is only through the medium of some corporeal being that it can raise itself again to contemplation of higher things. ${ }^{55}$

In one of the last scenes of Death in Venice, the traveller followed the Polish family to St. Mark's Square. Tadzio was then to look back and see if Aschenbach was following him. "Lured by those eyes," enced this situation so intensely that "His head burned, his body was wet with clammy sweat, he was plagued by intolerable thirst." ${ }^{\prime 7}$ Strong emotions manifested themselves in a morbid reaction of the body, vividly reminiscent of the effects of excessive sunshine or sunstroke. Aschenbach was so close to the source of the glow, both in the physical sense, since it seemed to him that the "love affair" with the boy burgeoned, and in the symbolic one when - lead by Eros - he experienced an excellent creative period and he was learning the divine nature of art, when he finally got burnt in its flame. The fate of the character is embedded in his name as asch in German means "ash."

The traveller is reminiscent of Icarus, the mythical aviator who, together with his father, wanted to reach the sky. But he got too close to the sun: the wax on the wing joints melted and the daredevil fell. "And here is Aschenbach, our Icarus, flying too high, melting and crashing down on a beach" ${ }^{\prime \prime 58}$ - as Michael Cunningham wrote about the protagonist of Death in Venice. The fall of Aschenbach appears to be ambiguous: it means not only the protagonist's death but also his moral degeneration as a person and as a writer. The figure of Icarus allows the reader to perceive the protagonist of Mann's work as a tragic figure and see further elements of ancient tragedy in the individual stages of his journey.

\section{The sun as a key}

Death in Venice is composed of references and reminiscences which force the reader to make intellectual journeys through European tradition. ${ }^{59}$ One of the references is the autobiographical aspect, since Mann endowed his hero with many of his own qualities. The author of The Magic Mountain skilfully blurs the line between real events and literary fiction. Another one is a peculiar "spiritual" topography: the places where Aschenbach lives imprint their mark on him, influence his feelings and modify his fundamentally Protestant attitude. For instance, the Byzantine chapel from the beginning of the story becomes the catalyst of all events, and tiredness of rainy $\mathrm{Mu}$ nich makes the protagonist look for new impressions.




The places which the writer visits are never just what they are, and they never represent only themselves. Venice is not Venice at all: in Aschenbach's imagination, it is transformed from the Italian city into the seat of Greek culture with a strong influence of the East (as indicated by the sightings of Dionysian animals, namely tigers, or indirectly by the traces in the story of the philosophy of Schopenhauer and Nietzsche, who drew inspiration from this cultural circle). As a result, Venice resembles more an amalgam of southern decadence and eastern lechery, which is an excellent counterpoint to the austere North. Since Death in Venice is constructed in such a way that the majority of the elements appearing in the finale of the novella is hinted at already in the beginning, the appearance of a Byzantine chapel suggests that for Aschenbach this pearl of the Adriatic is, in fact, the European Byzantium.

The story is set as if on two planes: real events and activities of the character are intertwined with events that are suggested by his imagination. Likewise, there are two time planes: the Venice of the early twentieth century meets with antiquity; and the present day with the mythical world. How can these elements create a harmonious whole? The key may be the figure of the sun, which carries an extremely rich meaning in the cultural message. It is due to this symbol that such different elements, such different time planes can co-exist.

The presence of the sun in Death in Venice is prevalent. In some cases, it is mentioned directly; on other occasions, it is more of a cultural reference. The symbolism of the sun is diversified, which is related to the dual perception of its essence. Sometimes the analogy of the sun and goodness comes to the fore, and sometimes the sun is seen as a threat - it can burn or confuse the senses.

In many writings, including in the work in question, Venice turns out to be a city of the sun, which is reflected in the symbolic sphere: the city of St. Mark is guarded by lions, animals associated precisely with the sun. As "half fairy-tale, half snare," Venice attracts tourists like the sun, which, according to the ancients, is sought by all souls hungry for beauty.

In Thomas Mann's novella, the character of Tadzio is sometimes identified with the sun on a number of levels. Its properties and symbolic meaning in solar mythology are transferred to the boy. This analogy can be seen in the external appearance and the way Tadzio moves. Moreover, the boy is sometimes Apollo, who is associated with Helios and Sol, the gods of the sun, and he also represents positive features attributed to this star, such as brightness, perfection, goodness and beauty. Tadzio also represents the pernicious powers of the sun: destructive sensuality, and the retreat from intellectual to bodily values. Finally, he is responsible - as Hermes - for taking Aschenbach to the other side, to the underground where the writer's soul will rest in peace in the eternally sunny Elysium.

The figure of the sun also allows for seeing the main character of Death in Venice in different light. His soul, lured by the beauty of the sun which is manifested by Tadzio, "is coming to an orgiastic end," ${ }^{60}$ as Mann used to say.

${ }^{60}$ Aleksander Rogalski, Tomasz Mann. Dzieje rozwoju osobowości twórczej (Warsaw: Instytut Wydawniczy PAX, 1975), 80. 
Aschenbach's death may be a metaphor of the fate which befell the mythical Icarus. The aging writer came too close to the sun, or to what it symbolises. The fascination with Tadzio turns out to have fatal consequences, which ancient thinkers warned against. The original fault, however, was that he was an artist: he had a strong need to strive for this aesthetic perfection, and, in search of creative fulfillment, he agreed to a morally questionable pact. Art has a destructive force, which is illustrated by the deadly march of Aschenbach, this modern Icarus, towards the sun.

Death in Venice by Thomas Mann is an extraordinary mosaic composed of many motifs, symbols and quotations, referring to the achievements of European culture. Depending on how the reader arranges these elements - which will be given priority and which will move to the background - a different picture of the whole will be obtained. In the opinion of the author of this article, the lens through which it is worth looking at this story is the presence of the sun, which was not been studied before. It is precisely the sun that is the catalyst for many associations with the ancient world: the sun makes it possible to link modernity with antiquity, and Venice, the city of carnival but also "half fairy-tale, half snare" ${ }^{\text {"61 }}$ becomes set in a mythological context. This key element of the solar mythology is an essential part of the symbolic tissue of the work, producing new interesting senses and allowing this elaborate mosaic to be opalescent with the new shine.

\section{REFERENCES}

Achtelik, Aleksandra. Wenecja mityczna w literaturze polskiej XIX i XX wieku. Katowice: Gnome, 2002.

Ackroyd, Peter. Venice: Pure City. New York: Random House, 2009, 146. Accessed October 24, 2020. https://kingauthor.net/books/Peter\%20Ackroyd/Venice/Venice\%20-\%20Peter\%20Ackroyd.pdf.

Alexander, Doris. Creating Literature out of Life. The Making of Four Masterpieces. Pennsylvania: The Pennsylvania State University, 1996.

Bieńkowska, Ewa. W poszukiwaniu królestwa człowieka. Utopia sztuki od Kanta do Tomasza Manna. Warsaw: Czytelnik, 1981.

Brann, Eva T.H. “The Venetian Phaedrus." St. John's College Digital Archives, 1972. Accessed April 28, 2020. http://digitalarchives.sjc.edu/items/ show/1234.

Cunningham, Michael. Introduction. In Mann, Thomas. Death in Venice. Translated by Michael Henry Heim. New York: Harper Collins, 2015.

Czaja, Dariusz. "Wenecja i śmierć. Konteksty symboliczne." Polska Sztuka Ludowa - Konteksty, no. 3-4 (1992): 58-65.

Encyklopedia Gutenberga. Accessed April, 27, 2020 http://www.gutenberg. czyz.org/word,63594.

${ }^{61}$ Mann, Death in Venice, 482. 
Foucault, Michel. Historia seksualności. Tranlated by Bogdan Banasiak, Tadeusz Komendant and Krzysztof Matuszewski. Gdańsk: słowo/obraz terytoria, 2010.

Jaworska-Witkowska, Monika. "Nienasycenie i 'niewygasła żywotność' archetypu wielkiej matki. Misterium 'rodzącego łona' jako symbol uniwersalizmu tworzenia." Rocznik Naukowy Kujawsko-Pomorskiej Szkoły Wyższej w Bydgoszczy. Transdyscyplinarne Studia o Kulturze (i) Edukacji, no. 7-8, 91-106.

Kurecka, Maria. Czarodziej. Rzecz o Tomaszu Mannie. Krakow: Oficyna Literacka, 1993.

Lesér, Esther. "An artist's call and fate: the nature of beauty." In Lesér, Esther. Thomas Mann's short fiction. An intellectual Biography. Cranbury: Associated University Presses, 1989, 161-180.

Mała encyklopedia kultury antycznej. Edited by Zdzisław Piszczek. Warsaw: PWN, 1983.

Mann, Thomas. Death in Venice. Translated by Helen Tracy Lowe-Porter. In Short Novels by the Masters. Edited by Charles Neider. New York: Cooper Square Press, 2001.

Mann, Thomas. "Lubeka jako duchowa forma życia." In Thomas Mann. O sobie: wybór pism autobiograficznych. Warsaw: Czytelnik, 1971, 16-32.

Muratow, Paweł. Obrazy Włoch. Wenecja. Translated by Paweł Hertz. Warsaw: Wydawnictwo Zeszytów Literackich, 2009.

Osiński, Alojzy. Słownik mitologiczny z przyłączeniem obrazu-pismo, vol. 1, Warsaw: Drukarnia Xięży Piarów, 1812. Accessed April 29, 2020. http:// mbc.cyfrowemazowsze.pl/dlibra/doccontent?id=6161.

Parkes, Ford. The Image of the Tiger in Thomas Mann's Tod in Venedig. Studies in 20th Century Literature, vol. 3, no. 1, (1978). Accessed 27 April 2020, https://doi.org/10.4148/2334-4415.1060.

Pausanias. Wędrówka po Helladzie. Księgi I-X. Computer edition, 2003. Accessed April 30, 2020. http://biblioteka.kijowski.pl/antyk\%20grecki/\%20 pauzaniasz\%20-\%20w\%E4\%99dr\%E3\%B3wka\%20po\%20helladzie\%20 ks.1-10.pdf.

Perczak, Edward. "Główne kierunki mitologii lunarnej." Studia Theologica Varsaviensia, no. 1 (1973): 241-254.

Pieniążek, Paweł. "Anatomia dekadencji." In Białek Edward, Kowal Grzegorz. Arcydzieła literatury niemieckojezycznej, vol. 2. Wrocław: ATUT, 2011, 181-192.

Plato. Państwo. Translated by Władysław Witwicki. Warsaw: PWN, 1958.

Plato. The Phaedrus. Translated by Benjamin Jowett. The Project Gutenberg EBook of Phaedrus, last modified January 15, 2013. Accessed October 25, 2020, http://www.gutenberg.org/files/1636/1636-h/1636-h.htm.

Rogalski, Aleksander. Tomasz Mann. Dzieje rozwoju osobowości twórczej. Warsaw: Instytut Wydawniczy PAX, 1975.

Sizemore, John, Jr. "An analysis of art represented in classical mythology in Mann's Death in Venice," International Jornal of Arts \& Sciences (2014). Accessed 27 April 2020, http://www.universitypublications.net/ijas/0705/ pdf/H4V180.pdf. 
Smith, William. A dictionary of the Greek and Roman Biography and Mythology. Boston: Little, 1887.

Stabryła, Stanisław. Zarys kultury starożytnej Grecji i Rzymu. Warsaw: Wydawnictwo Naukowe PWN, 2007.

Tatarkiewicz, Władysław. Historia filozofii, vol. 1. Warsaw: Wydawnictwo Naukowe PWN, 2009.

Willis, Louise. "The Representation of Instinctive Homosexuality and Immoral Narcissism in Gide's The Immoralist (1902) and Mann's Death in Venice (1912)," CLCWeb: Comparative Literature and Culture (2017). Accessed April 27, 2020. https://doi.org/10.7771/1481-4374.2960.

Wołk, Marcin. Głosy labiryntu. Od "Śmierci w Wenecji" do "Monizy Clavier." Torun: Wydawnictwo Naukowe Uniwersytetu Mikołaja Kopernika, 2009.

Zipper, Albert. Mitologia Greków i Rzymian. Złotów: Wydawnictwo Księgarni Wilhelma Zukerkandla, 1896.

Anna Sieradzan - a graduate of Polish Philology at the Faculty of Polish Studies at the University of Warsaw and Journalism and Media Studies at the Faculty of Journalism, Information and Book Studies at the University of Warsaw, where she is doing her doctoral studies. She co-operated with Polskie Radio Program II from 2014 to 2019. In her research work she deals with, among other things, radio broadcasting from the genre-related perspective as well as links between radio and literature.

E-mail: anna.sieradzan@uw.edu.pl 